Article

\title{
Synthesis and Characterization of Wooden Magnetic Activated Carbon Fibers with Hierarchical Pore Structures
}

\author{
Dongna Li ${ }^{1,2}$, Jianing $\mathrm{Li}^{1}$, Biyun Ren ${ }^{2}$, Tongtong $\mathrm{Li}^{1}$ and Xiaojun $\mathrm{Ma}^{2, *}$ \\ 1 Ministry of AgricultureKey Laboratory of Biology and Genetic Resource Utilization of Rubber Tree/State \\ Key Laboratory Breeding Base of Cultivation \& Physiology for Tropical Crops, Rubber Research Institute, \\ Chinese Academy of Tropical Agricultural Sciences, Danzhou 571737, China; lidnqiaoh@126.com (D.L.); \\ ljn206@163.com (J.L.); tongxinltt@163.com (T.L.) \\ 2 College of Packaging \& Printing Engineering, Tianjin University of Science \& Technology, Tianjin 300222, \\ China; byren2-c@my.cityu.edu.hk \\ * Correspondence: mxj75@tust.edu.cn; Tel.: +86-22-6060-0883
}

Received: 16 March 2018; Accepted: 11 April 2018; Published: 13 April 2018

\begin{abstract}
Wooden magnetic activated carbon fibers (WMACFs) with hierarchical pore structures were obtained by adding magnetic iron oxide $\left(\mathrm{Fe}_{3} \mathrm{O}_{4}\right)$ nanoparticles into the liquefied wood. The structures and properties of WMACFs were analyzed by scanning electronmicroscopy (SEM), X-ray diffraction (XRD), Fourier transform infrared spectroscopy (FTIR), $\mathrm{N}_{2}$ adsorption, and vibrating sample magnetometer (VSM). The results showed that WMACFs had high Brunauer-Emmett-Teller (BET) surface area $\left(1578 \mathrm{~m}^{2} / \mathrm{g}\right)$ and total pore volume $\left(0.929 \mathrm{~cm}^{3} / \mathrm{g}\right)$, of which $45 \%$ was the contribution of small mesopores of 2-3 nm. It is believed that $\mathrm{Fe}_{3} \mathrm{O}_{4}$ nanoparticles play an important role in the formation of hierarchical pores. With the $\mathrm{Fe}_{3} \mathrm{O}_{4}$ content increasing, the yield rate of WMACFs decreased, and the $\mathrm{Fe}_{3} \mathrm{O}_{4}$ crystal plane diffraction peaks and characteristic adsorption peaks were obviously observed. At the same time, it was also found that WMACFs had favorable magnetic properties when the $\mathrm{Fe}_{3} \mathrm{O}_{4}$ content was above $1.5 \%$. As a result, WMACFs could be a promising candidate for high efficiency, low cost, and convenient separation for the magnetic field.
\end{abstract}

Keywords: magnetic iron oxide nanoparticles; wooden activated carbon fiber; biocompatible; adsorption; magnetic properties

\section{Introduction}

Activated carbon fibers (ACFs), which have uniform slit-shaped micropores and great surface area, have played a major role in adsorption technology over the last few years [1]. However, ACFs are microporous with pore diameter ranging from 0.3 to $0.5 \mathrm{~nm}$ [2], resulting in challenges for applying ACFs in some areas, especially those that require adsorption of bulky molecules from solutions and macromolecular reactions with catalyst supports evolved. Recently, ACFs with hierarchical pore structures have attracted much attention because of their excellent adsorptive properties based on highly developed multi-porous structures [3-5]. Various methods have been carried out to prepare ACFs with hierarchical pore structures. For example, previous research has shown that wooden activated carbon fibers (WACFs) with highly developed mesopores have been successfully prepared by steam activation with the addition of wood charcoal, resulting in the specific Brunauer-Emmett-Teller surface area $\left(S_{\mathrm{BET}}\right)$ and the ratio of the mesopore volume to the total pore volume (MP-ratio) of ACFs increasing significantly [6,7].

Moreover, the used ACFs often suffer from serious problems of separation in liquid-solid phase processes and cause secondary pollution to the environment [8]. Magnetic technology makes it possible 
to effectively separate and recover the spent ACFs through a simple magnetic process and exhibits excellent ability to separate nanosized materials with many advantages, including easy operation and low cost [9]. $\mathrm{Fe}_{3} \mathrm{O}_{4}$ nanoparticles are the most popular and commonly used magnetic source in magnetic separation due to its superior magnetic performance, low toxicity, and easy preparation [10]. $\mathrm{Li}$ et al. [11] designed and prepared a unique, multifunctional $\mathrm{Fe}_{3} \mathrm{O}_{4}$-activated carbon-sodium alginate composite absorbent (MSA-AC) that extracted dye from aqueous solutions. The results revealed that the MSA-AC has a potential application in wastewater treatment and in the development of composite absorbent that is simple and fast to prepare, cost-effective, and environmentally friendly. Shi et al. [12] prepared carbon-iron composites from waste cation exchange resin through $\mathrm{NaOH}$ activation. The composite, synthesized at $800{ }^{\circ} \mathrm{C}$, could effectively remove diethyl phthalate, bisphenol $\mathrm{A}$, and malachite green from aqueous solutions. Yang et al. [13] synthesized magnetic $\mathrm{Fe}_{3} \mathrm{O}_{4}$-activated carbon nanocomposite from rice husk based activated carbon. The system demonstrated perfect magnetic separation performance and a high adsorption capacity of $321 \mathrm{mg} / \mathrm{g}$ for methylene blue (MB) from aqueous solutions. It is expected that the obtained magnetic materials can be used as potential sorbents for the removal of various toxic pollutants from wastewater. In recent years, scholars have explored the introduction of magnetic nanoparticles into ACFs and have become more focused on physically mixing ACFs with metallic oxide before carbonization and activation to obtain ACFs with hierarchical pore structures through the catalytic activation method $[14,15]$. It is expected that $\mathrm{Fe}_{3} \mathrm{O}_{4}$ nanoparticles as additives will play an important role in the multi-pore formation of ACFs. Currently, most methods synthesize $\mathrm{Fe}_{3} \mathrm{O}_{4}$ in a carbon matrix using activated carbon materials as the carbon source, such as using the impregnating method in $\mathrm{Fe}^{3+}$ solution [16]. This, however, only loads the magnetic nanoparticles on the surface of the ACFs, and the supported nanoparticles easily fall off, resulting in the decrease of the adsorption capacity and reuse times after adsorption saturation. Very few studies have been done that combine $\mathrm{Fe}_{3} \mathrm{O}_{4}$ nanoparticles with WACFs.

Based on our previous work $[17,18]$, using $\mathrm{Fe}_{3} \mathrm{O}_{4}$ nanoparticles as an additive, wooden magnetic activated carbon fibers (WMACFs) from Chinese fir (Cunninghamia lanceolata) were prepared by phenol liquefaction, melt spinning, curing, and activation using steam. The morphological, chemical, and microcrystalline structures of the synthesized WMACFs were characterized using a wide array of analytical methods. In addition, in order to understand the relationship between $\mathrm{Fe}_{3} \mathrm{O}_{4}$ contents, pore size distribution, and magnetic properties, the WMACFs were studied. The effects of different $\mathrm{Fe}_{3} \mathrm{O}_{4}$ contents on the specific surface area and magnetic properties were investigated in detail by $\mathrm{N}_{2}$ adsorption and vibrating sample magnetometer (VSM). This study effectively solves the disadvantages of the impregnating method and can obviously increase reuse times. It also provides reference value for further research.

\section{Materials and Methods}

\subsection{Samples}

Chinese fir (Cunninghamia lanceolata) was firstly ground and screened to a particle size of 60-80 meshes to prepare the precursor fibers through a series of processes, including liquefaction, adding nano- $\mathrm{Fe}_{3} \mathrm{O}_{4}$ (Fe content $\geq 95 \%$, relative density was $5.18 \mathrm{~g} / \mathrm{cm}^{3}$, melting point was $1594{ }^{\circ} \mathrm{C}$ ), melt-spinning, and curing in accordance with previous studies $[19,20]$. The precursors were put in a tube furnace, and the activation process was conducted with a temperature program from room temperature to the final activation temperature $\left(800^{\circ} \mathrm{C}\right)$ using a heating rate of $5{ }^{\circ} \mathrm{C} / \mathrm{min}$ under $\mathrm{N}_{2}$ $\left(200 \mathrm{~cm}^{3} / \mathrm{min}\right)$. The precursors were held isothermally for $40 \mathrm{~min}$ under a steam flow of $8 \mathrm{~g} / \mathrm{min}$ and then cooled to room temperature to obtain the WMACFs [21]. Various contents (0-2.5 wt \%) of $\mathrm{Fe}_{3} \mathrm{O}_{4}$ were used to investigate its influence on the WMACFs. The schematic of the production process is shown in Figure 1. 


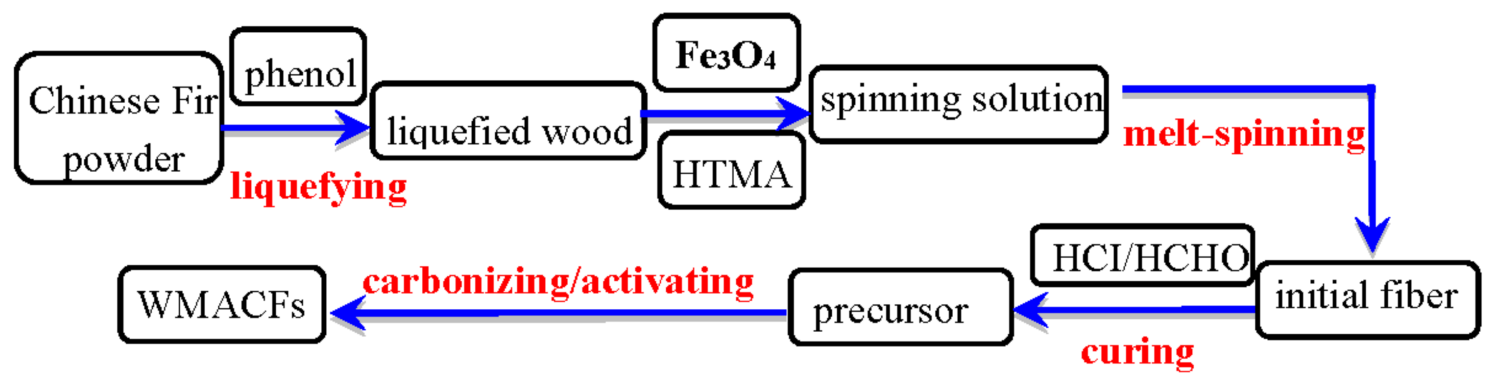

Figure 1. Schematic of the production process of the wooden magnetic activated carbon fibers (WMACFs). HTMA: hexamethylenetetramine; HCI: hydrochloric acid; and HCHO: formaldehyde.

\subsection{Characterizations}

The surface morphologies of the WMACFs were examined using a SEM (NOVA Nano SEM430, FEI, Hillsboro, OR, USA) with an acceleration voltage of $10 \mathrm{keV}$.

The X-ray diffraction (XRD) analyses of the WMACFs were carried out at room temperature on a power X-ray diffractometer (D/max-2500, Rigaku, Tokyo, Japan) using $\mathrm{Cu} \mathrm{K \alpha}$ radiation (wavelength was $0.154 \mathrm{~nm}$, powdered samples). The XRD analysis conditions were as follows: scanning range of $5^{\circ}-60^{\circ}$, scanning rate of $2^{\circ} / \mathrm{min}$ at $40 \mathrm{kV}$ and $100 \mathrm{~mA}$.

In order to examine the differences between the microcrystalline structures of the WMACFs at various $\mathrm{Fe}_{3} \mathrm{O}_{4}$ contents, the apparent value of the planar size $\left(\mathrm{La}_{(110)}\right)$, the bulk thickness $\left(L c_{(002)}\right)$ of the graphite sheet layer, the average crystallite size $(D)$, and the layer spacing $d_{002}$ were calculated using the Scherrer and Bragg formulas [22,23]. The formulas were as follows:

$$
\begin{gathered}
L \mathrm{c}_{(002)}, D=0.89 \lambda / \beta \cos \theta \\
\operatorname{La}_{(110)}=1.84 \lambda / \beta \cos \theta \\
d_{002}=\lambda / 2 \sin \theta
\end{gathered}
$$

where $\lambda$ is the wavelength of the $X$-ray $(0.154 \mathrm{~nm}) ; \theta$ is the Bragg angle of (002), (100), and (311) peaks $\left(^{\circ}\right)$; and $\beta$ is the half-height width of (002), (100), and (311) peaks (rad).

The graphitization degree of the WMACFs can be calculated by the layer spacing $d_{002}$ [24]. The simplified formula is

$$
g=\left(0.3440-d_{002}\right) /(0.3440-0.3554)
$$

where $g$ is the graphitization degree (\%); 0.3440 is the layer spacing of not completely graphited carbon material (nm); 0.3354 is the layer spacing of the ideal graphite crystal (nm); and $d_{002}$ is the layer spacing $(\mathrm{nm})$.

The chemical characterization of the functional groups was detected using pressed potassium bromide $(\mathrm{KBr})$ pellets containing $5 \%$ of the sample by Fourier-transform infrared spectrometry (Nicolet-6700, Thermo electron, Waltham, MA, USA) in the scanning range of $4000-500 \mathrm{~cm}^{-1}$.

The specific surface area and the porosity of the samples were determined by $\mathrm{N}_{2}$ adsorption-desorption isotherm measured at $77 \mathrm{~K}$ in a Micromeritics ASAP-2020 apparatus (Micromeritics, Norcross, GA, USA. Before analysis, the samples were degassed at $350{ }^{\circ} \mathrm{C}$ for $2 \mathrm{~h}$. The $\mathrm{S}_{\mathrm{BET}}$ was calculated by the Brunauer-Emmett-Teller (BET) method using the $\mathrm{N}_{2}$ adsorption isotherm data. The total pore volume $\left(V_{\text {tot }}\right)$ was evaluated by converting the amount of $\mathrm{N}_{2}$ adsorbed at a relative pressure of 0.995 to the volume of the liquid adsorbate. The micropore area $\left(S_{\text {micro }}\right)$ and micropore volume $\left(V_{\text {micro }}\right)$ were obtained by t-plot method [25]. The mesopore area $\left(S_{\text {meso }}\right)$ and mesopore volume $\left(V_{\text {meso }}\right)$ were calculated by Barrett-Joyner-Halenda $(\mathrm{BJH})$ method [26]. Pore size distributions were calculated using the density functional theory (DFT) Plus software (provided by Micromeritics Instrument Corporation (Georgia, USA), which was based on calculated adsorption 
isotherms for pores of different sizes [27]. This program performs an inversion of the integral equation for the overall adsorption isotherm with respect to pore size distributions.

The yield rate $\eta$ of the WMACFs can be expressed as:

$$
\eta=m / m_{0} \times 100 \%
$$

where $m_{0}$ and $m$ are the masses of the specimen before and after activation, respectively.

The magnetic properties of the WMACFs were measured with a Lake Shore 7304 VSM (Lakeshore, Columbus, MS, USA) at room temperature.

\section{Results and Discussion}

\subsection{Morphological Characteristics of the WMACFs}

The SEM images of the surfaces of the WACFs and the WMACFs are shown in Figure 2a-f. It is obvious that the WACFs (Figure $2 a, b$ ) have a smooth surface and uniform thickness without surface deposits, and that they maintain porous structures on the inner and outer surface. Figure $2 c-f$ shows that $\mathrm{Fe}_{3} \mathrm{O}_{4}$ nanoparticles were deposited on almost every WMCAF with non-uniform distribution, and the $\mathrm{Fe}_{3} \mathrm{O}_{4}$ particles' agglomeration and pores can be clearly observed.

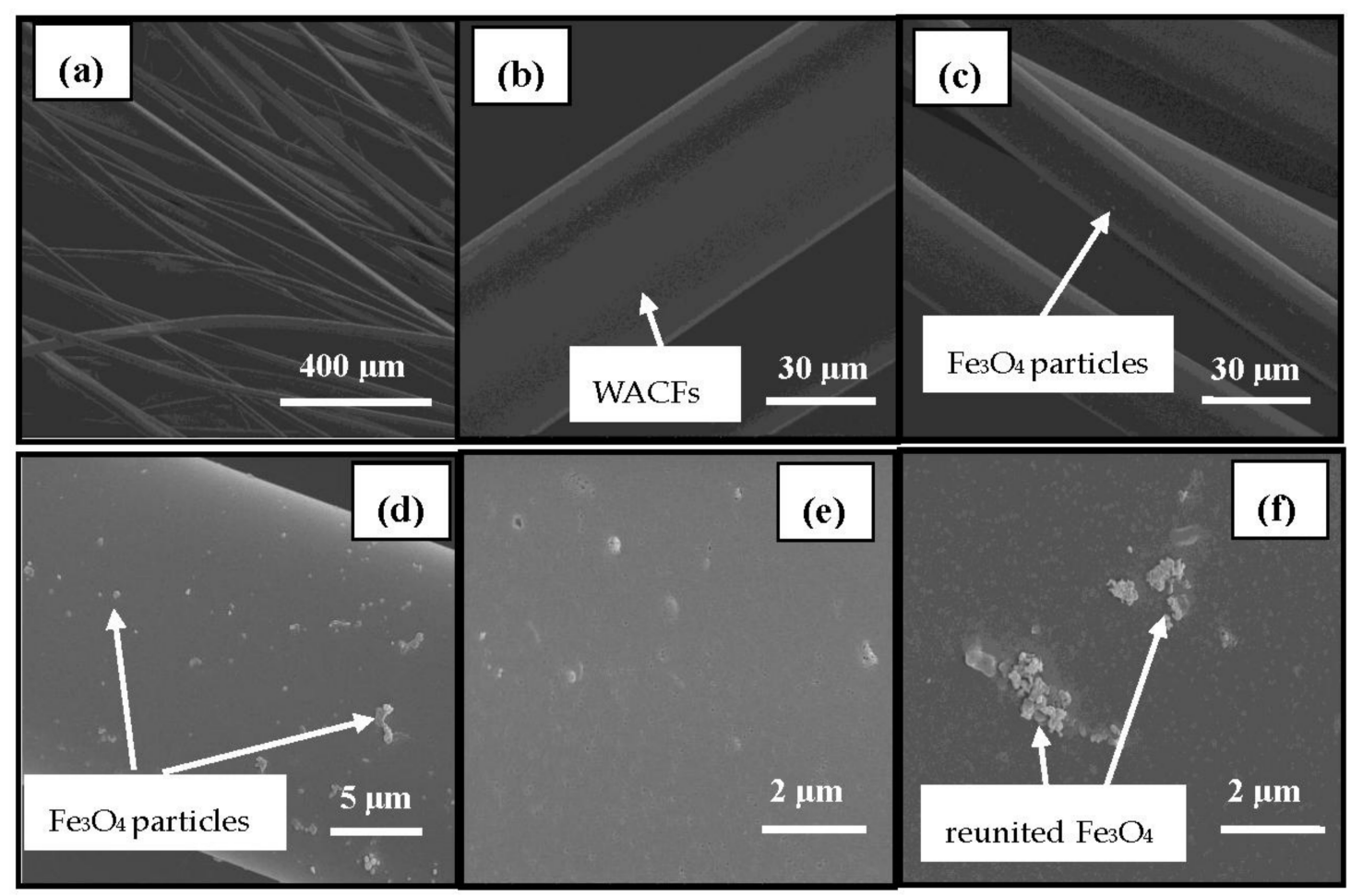

Figure 2. Surface SEM photographs of wooden activated carbon fibers (WACFs) (a,b) and WMACFs $\left(2.5 \% \mathrm{Fe}_{3} \mathrm{O}_{4}\right.$ content) $(\mathbf{c}-\mathbf{f})$.

Figure 3 shows a SEM image of a cross-section of the WACFs (Figure 3a,b) and WMACFs (Figure 3c,d). Figure 3a,b shows that the cross-section of the WACFs was round or elliptical, and some unevenly distributed pores were possibly caused by the number of escaping non-carbon atoms, which increased during the carbonization and activation process. Figure $3 c$,d shows that some $\mathrm{Fe}_{3} \mathrm{O}_{4}$ particles were present. It was found that the granular $\mathrm{Fe}_{3} \mathrm{O}_{4}$ was also deposited onto the cross-section of the WMACFs during the reaction. 

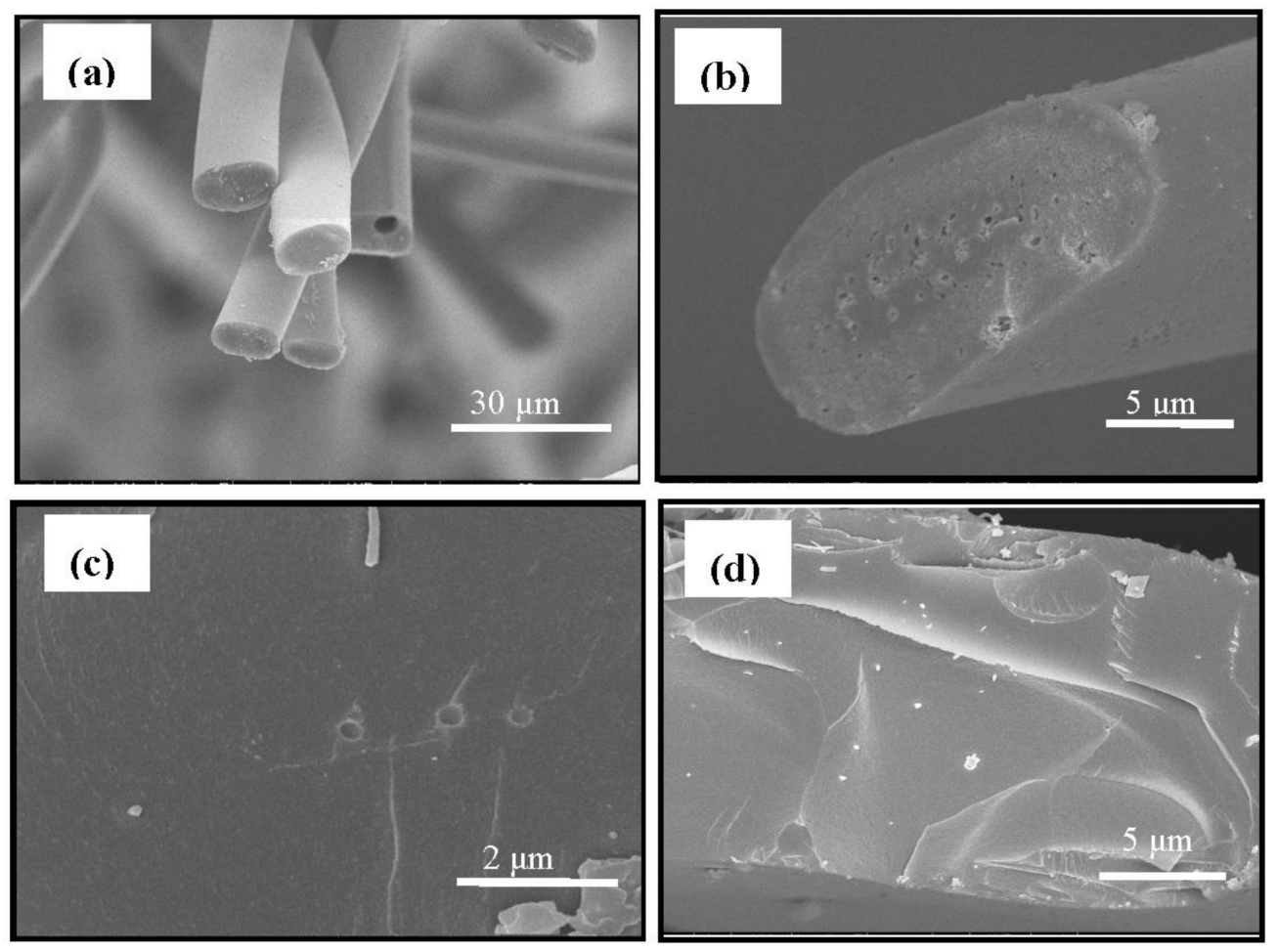

Figure 3. Cross-sectional SEM photographs of the WACFs $(\mathbf{a}, \mathbf{b})$ and WMACFs $\left(2.5 \% \mathrm{Fe}_{3} \mathrm{O}_{4}\right.$ content) (c,d).

\subsection{XRD Analysis of the WMACFs}

Figure 4a showed the XRD patterns of the WACFs and WMACFs at various $\mathrm{Fe}_{3} \mathrm{O}_{4}$ contents. The observed peaks at $2 \theta=21.3^{\circ}$ and $43.9^{\circ}$ were (002) and (100) peaks of disordered graphite microcrystals in the WACFs, respectively [28]. The occurrence of the dominant peaks at $2 \theta=30.3^{\circ}$, $35.3^{\circ}, 43.5^{\circ}, 57^{\circ}$, and $62.7^{\circ}$ could correspond to (220), (311), (400), (511), and (440) crystal planes of a pure $\mathrm{Fe}_{3} \mathrm{O}_{4}$ with a spinal structure (JCPDS file (PDF No. 65-3107)) [29]. All of the above were the characteristic diffraction peaks of $\mathrm{Fe}_{3} \mathrm{O}_{4}[30,31]$, indicating that $\mathrm{Fe}_{3} \mathrm{O}_{4}$ had been introduced into the WACFs. As the nano- $\mathrm{Fe}_{3} \mathrm{O}_{4}$ content was low, its peaks' intensities were relatively weak, especially when the content was $0.5 \%$ and $1 \%$. With increased $\mathrm{Fe}_{3} \mathrm{O}_{4}$ content, the diffraction peaks were narrowed and became more prominent. It was significant that the changes of (220) and (400) peaks, which indicated the crystallization degree of $\mathrm{Fe}_{3} \mathrm{O}_{4}$, were enhanced. In addition, for the samples of 1.5-2.5\% $\mathrm{Fe}_{3} \mathrm{O}_{4}$ content, the diffraction peak at $2 \theta=28^{\circ}-30.3^{\circ}$ had a great change compared with other samples, displaying the double peaks phenomenon. This was probably because under the high-temperature activation process, with the increase of the $\mathrm{Fe}_{3} \mathrm{O}_{4}$ content, the structure of the samples had undergone a phase transformation from single-phase to two-phase, maintaining a two-phase coexistence state.

As shown from the XRD structure parameters (Table 1$), d_{002}, L_{\mathrm{c}(002)}, L_{\mathrm{a}(100)}$, and g were calculated by Formulas (1)-(4), respectively. $\beta$ of (002) and (100) peaks was clearly seen in Figure $4 b, c$. From the calculation results, the increase of the $\mathrm{Fe}_{3} \mathrm{O}_{4}$ content from $0 \%$ to $2.5 \%$ led to an obvious decrease in $d_{002}$ from 0.4931 to $0.3237 \mathrm{~nm}$. It can be concluded that the $\mathrm{Fe}_{3} \mathrm{O}_{4}$ content had a significant influence on the $d_{002}$. In addition, the bulk thickness $\left(L_{\mathrm{c}(002)}\right)$ and the apparent layer-plane length parallel to the fibers axis $\left(L_{\mathrm{a}(100)}\right)$ increased from 0.9561 to $1.064 \mathrm{~nm}$ and from 3.232 to $4.303 \mathrm{~nm}$, respectively. The $L_{\mathrm{c}} / d_{002}$ and $\mathrm{g}$ value corresponding to the change degree of graphitization structure also increased. The overall increase of $L_{\mathrm{c}(002)}$ was due to the fact that a large number of substances of aromatic structure that formed during the carbonization and activation process gradually changed into graphite-like 
microcrystalite structures of multilayer stacks. Correspondingly, the increase of $L_{\mathrm{a}(100)}$ indicated that a more regular and ordered carbon structure had been formed with the increased $\mathrm{Fe}_{3} \mathrm{O}_{4}$ content.
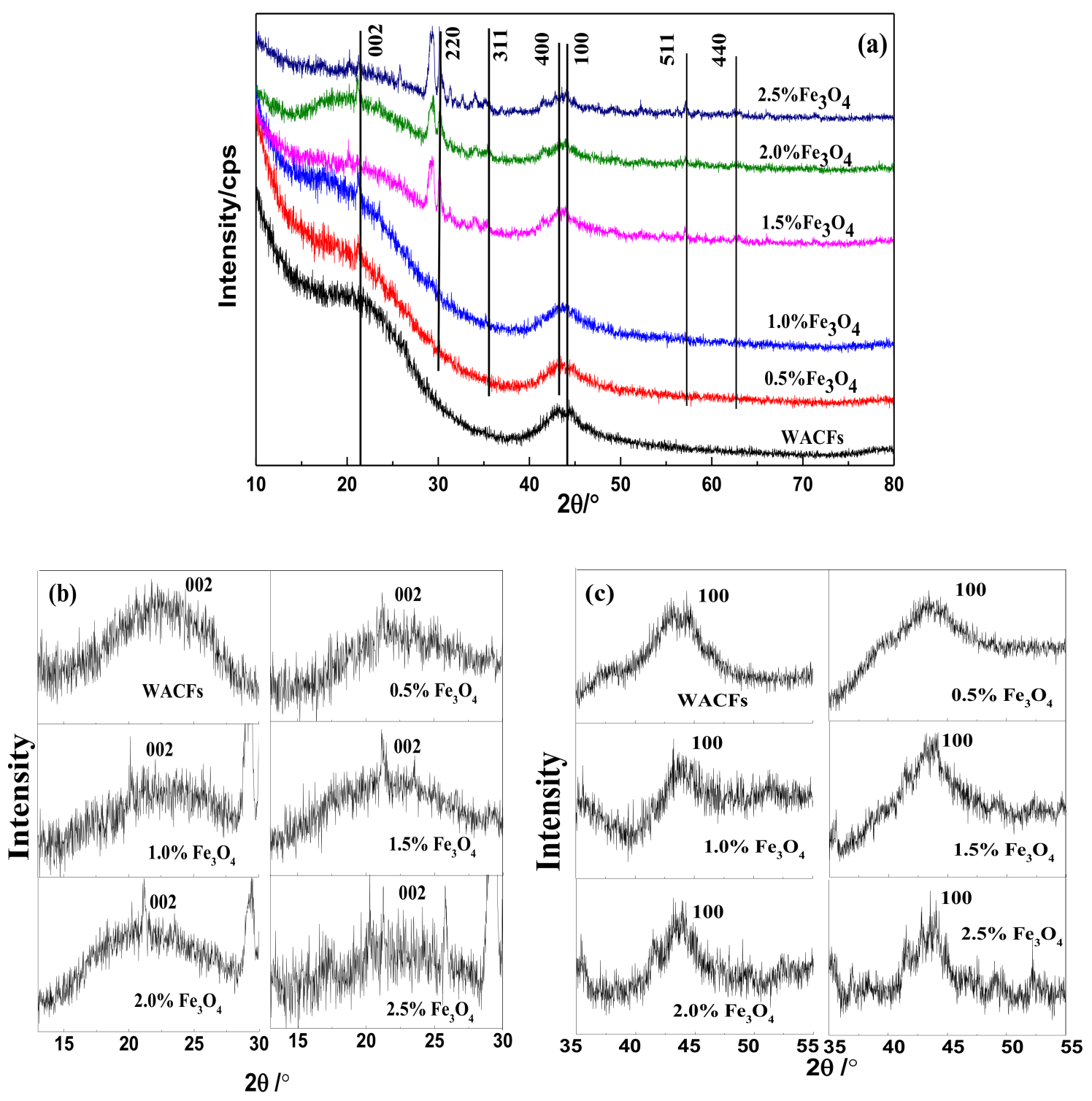

Figure 4. (a) XRD pattern of the WACFs and WMACFs at various $\mathrm{Fe}_{3} \mathrm{O}_{4}$ contents; (b,c) Local magnification curve of (002) and (100) peaks at various $\mathrm{Fe}_{3} \mathrm{O}_{4}$ contents.

Table 1. XRD structure parameters for the WMACFs.

\begin{tabular}{cccccc}
\hline $\mathbf{F e}_{\mathbf{3}} \mathbf{O}_{\mathbf{4}}$ Content & $d_{(\mathbf{0 0 2})} / \mathbf{n m}$ & $\mathbf{L c}_{\mathbf{( 0 0 2 )}} / \mathbf{n m}$ & $\mathbf{L a}_{(\mathbf{1 0 0})} / \mathbf{n m}$ & $L \mathbf{c} / d_{(\mathbf{0 0 2})}$ & $g / \%$ \\
\hline $0 \%$ & 0.4931 & 0.9561 & 3.232 & 1.939 & -17.34 \\
$0.5 \%$ & 0.5657 & 0.9350 & 3.027 & 1.653 & -25.78 \\
$1.0 \%$ & 0.5491 & 0.9554 & 3.625 & 1.739 & -23.86 \\
$1.5 \%$ & 0.4635 & 0.9748 & 3.809 & 2.103 & -13.89 \\
$2.0 \%$ & 0.4553 & 1.003 & 4.239 & 2.203 & -12.94 \\
$2.5 \%$ & 0.3237 & 1.064 & 4.303 & 3.287 & 2.36 \\
\hline
\end{tabular}

Table 2 shows the nanoparticle size of $\mathrm{Fe}_{3} \mathrm{O}_{4}$ as calculated by Formula (1). It can be observed that the average crystallite size of $\mathrm{Fe}_{3} \mathrm{O}_{4}$ was rather small, in the range of 10-19 nm. The reasons 
for the smaller particle size might be that the $\mathrm{Fe}_{3} \mathrm{O}_{4}$ particles were evenly and firmly dispersed on the surface of the WMACFs, without aggregation, providing a superior condition for the adsorption and separation.

Table 2. Relationship between the $\mathrm{Fe}_{3} \mathrm{O}_{4}$ content and the average crystallite size of $\mathrm{Fe}_{3} \mathrm{O}_{4}$.

\begin{tabular}{lccccc}
\hline $\mathrm{Fe}_{3} \mathrm{O}_{4}$ Content & $0.5 \%$ & $1 \%$ & $1.5 \%$ & $2 \%$ & $2.5 \%$ \\
\hline Average Crystallite Size & $18.73 \mathrm{~nm}$ & $14.22 \mathrm{~nm}$ & $11.13 \mathrm{~nm}$ & $11.45 \mathrm{~nm}$ & $10.58 \mathrm{~nm}$ \\
\hline
\end{tabular}

\subsection{FTIR Analysis of the WMACFs}

Figure 5a shows the FTIR spectra of the WACFs and WMACFs at various $\mathrm{Fe}_{3} \mathrm{O}_{4}$ contents, respectively. The position and shape of the band at $3420 \mathrm{~cm}^{-1}(-\mathrm{OH})$ were compatible with the involvement of hydrogen-bonded hydroxyl groups. The band at $3420 \mathrm{~cm}^{-1}$ was slightly broader towards the lower wavelengths, suggesting that some OH-ether hydrogen bonds were present. Weak bands at $1400 \mathrm{~cm}^{-1}$ were the stretching vibration of non-associated $-\mathrm{OH}$. The $1640 \mathrm{~cm}^{-1}$ band indicated that a variety of $\mathrm{C}=\mathrm{C}$ bonds existed besides those in aromatic rings. Both the WACFs and WMACFs showed weak adsorption peaks at 2980, 2921, and $2855 \mathrm{~cm}^{-1}$, which were due to the stretching vibration of $\mathrm{C}-\mathrm{H}[5,32]$. The broad band at $1100 \mathrm{~cm}^{-1}$ was the stretching vibration of $\mathrm{C}-\mathrm{O}-\mathrm{C}$ and $\mathrm{C}-\mathrm{O}-\mathrm{H}$, whose vibrations became flat. The adsorption peaks at $900 \mathrm{~cm}^{-1}(\mathrm{C}-\mathrm{C})$ decreased. The new band at $584 \mathrm{~cm}^{-1}$ (Figure $5 \mathrm{~b}$ ) could be attributed to the stretching vibrations of $\mathrm{Fe}-\mathrm{O}$ [10]. It proved that $\mathrm{Fe}_{3} \mathrm{O}_{4}$ was well-deposited on the WMACFs. As the nano- $\mathrm{Fe}_{3} \mathrm{O}_{4}$ content was low, its adsorption peak was relatively weak.
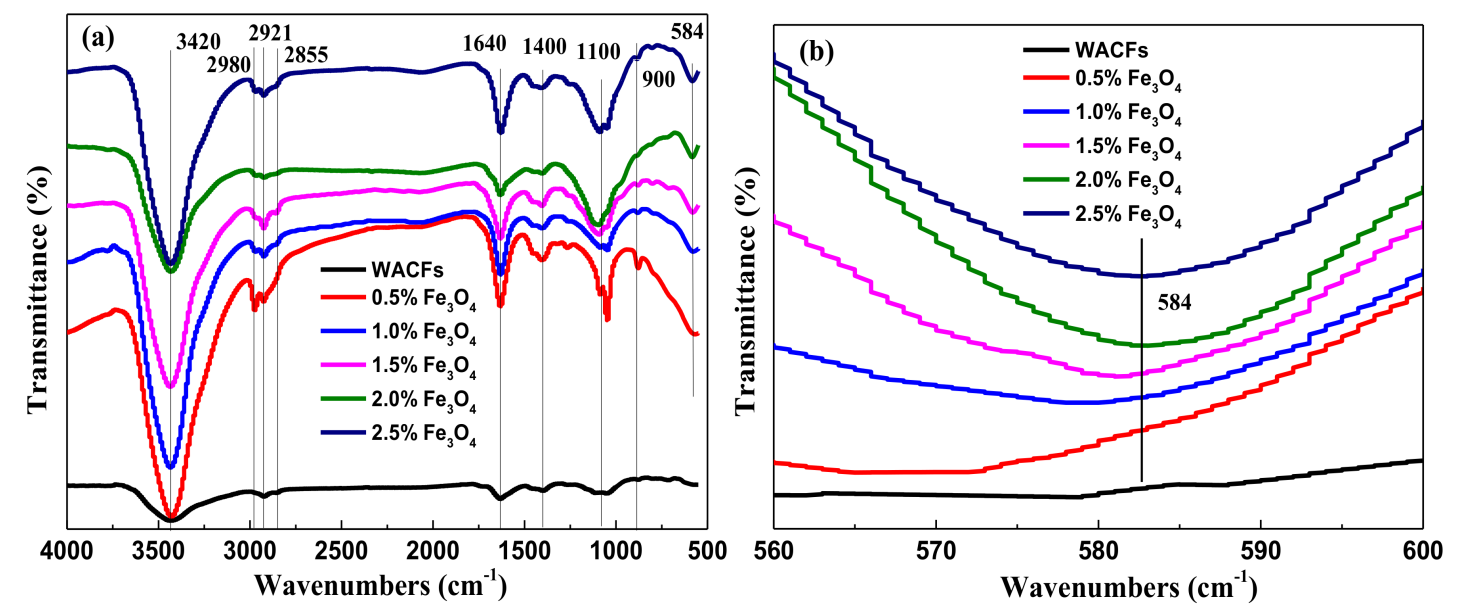

Figure 5. (a) FTIR of the WACFs and WMACFs at various $\mathrm{Fe}_{3} \mathrm{O}_{4}$ contents; (b) Local magnification curve of $584 \mathrm{~cm}^{-1}$ vibrationsat various $\mathrm{Fe}_{3} \mathrm{O}_{4}$ contents.

\subsection{Adsorption Characteristics, Specific Surface Area, and Pore Distribution of the WMACFs}

Figure 6 showed the $\mathrm{N}_{2}$ adsorption-desorption isotherms and pores size distribution of the WACFs and WMACFs, respectively. The adsorption isotherm of the WACFs and WMACFs of $0.5 \%$ $\mathrm{Fe}_{3} \mathrm{O}_{4}$ content was typical type I, based on the International Union of Pure and Applied Chemistry (IUPAC) classification where microporous adsorption was dominating, also called the Langmuir isother [33,34]. The isotherm profiles of the WMACFs (except for $0.5 \% \mathrm{Fe}_{3} \mathrm{O}_{4}$ content) belonged to typical type IV in which an adsorption/desorption hysteresis loop was visible, which can be ascribed to a defining characteristic of mesoporosity $[35,36]$. This meant that the $\mathrm{Fe}_{3} \mathrm{O}_{4}$ content had a great effect on the development of mesoporosity. 
As shown in Figure 6, the pore size distribution of the WMACFs can be divided into two prominent parts. The first part demonstrated a few peaks that were sharp and occurred at ca. 0.5 and $1.2 \mathrm{~nm}$. The second part was in the range between 2.0 and $3.0 \mathrm{~nm}$. This demonstrated that the WMACFs were a combination of micropores and mesopores with hierarchical pore structures. However, the microporous structure was still dominant.
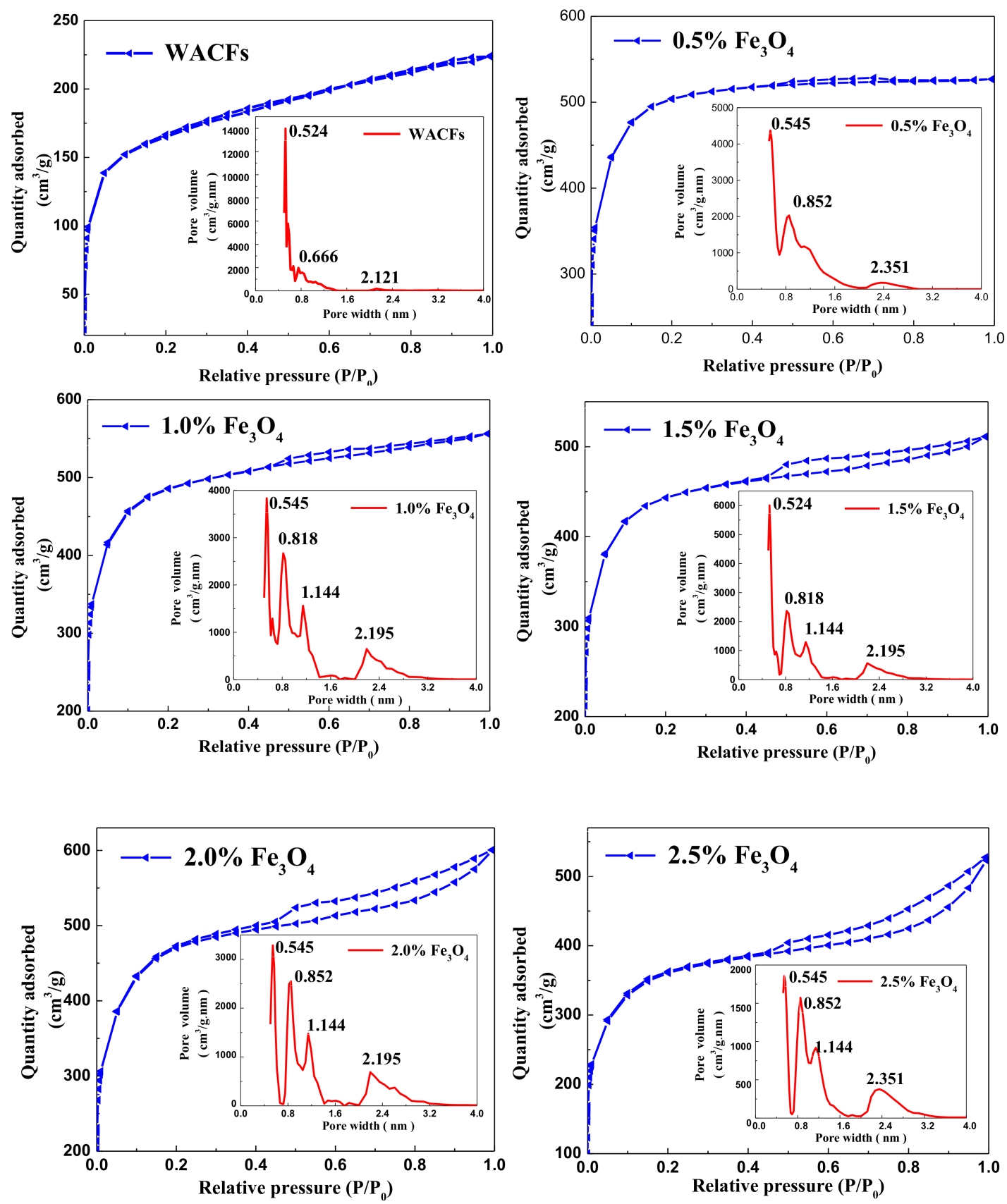

Figure 6. Nitrogen adsorption-desorption isotherms and pores size distribution of the WACFs and WMACFs.

The textural parameters of the WMACFs are listed in Table 3. As the $\mathrm{Fe}_{3} \mathrm{O}_{4}$ content was increased from $0 \%$ to $2.5 \%$, the $S_{\mathrm{BET}}, S_{\text {micro, }}$ and $V_{\text {micro }}$ all showed decreasing trends; the $V_{\text {tot }}$ gradually decreased and then increased. However, the $S_{\text {meso }}, V_{\text {meso }}$, and MP-ratio were increased. Especially when the $\mathrm{Fe}_{3} \mathrm{O}_{4}$ content was increased from $0 \%$ to $0.5 \%$, both the $S_{\text {meso }}$ and $V_{\text {meso }}$ increased by $68.47 \%$ and $71.83 \%$, respectively. This indicated that after adding $\mathrm{Fe}_{3} \mathrm{O}_{4}$, the ultra-micropores were enlarged, 
and most of them were further developed to mesopores, especially at a $\mathrm{Fe}_{3} \mathrm{O}_{4}$ content of $0.5 \%$. However, when the $\mathrm{Fe}_{3} \mathrm{O}_{4}$ content was too high, the decrease of $S_{\mathrm{BET}}$ suggested the formation of mesopores with hierarchical pore structures. As shown in Figure 7, the micropore proportion in the total pore volume and yield rate decreased from $90.93 \%$ and $33.9 \%$ to $51.02 \%$ and $18.8 \%$, respectively. The yield rate of the WMACFs via activation had an obvious decrease due to the fact that more carbon was eroded to develop the porosity. This was also related to the pore-forming and pore-expanding function of $\mathrm{Fe}_{3} \mathrm{O}_{4}$.

Table 3. The textural parameters of the WMACFs from the adsorption isotherms of nitrogen ${ }^{1}$.

\begin{tabular}{cccccccc}
\hline $\mathrm{Fe}_{3} \mathrm{O}_{\mathbf{4}}$ Content & $S_{\text {BET }}\left(\mathbf{m}^{2} / \mathbf{g}\right)$ & $S_{\text {micro }}\left(\mathbf{m}^{2} / \mathbf{g}\right)$ & $S_{\text {meso }}\left(\mathbf{m}^{2} / \mathbf{g}\right)$ & $V_{\text {tot }}\left(\mathbf{m}^{2} / \mathbf{g}\right)$ & $V_{\text {micro }}\left(\mathbf{m}^{2} / \mathbf{g}\right)$ & $V_{\text {meso }}\left(\mathbf{m}^{2} / \mathbf{g}\right)$ & MP-Ratio $(\%)$ \\
\hline $0 \%$ & 1173 & 1090 & 64 & 0.551 & 0.501 & 0.040 & 7 \\
$0.5 \%$ & 1894 & 1667 & 203 & 0.858 & 0.702 & 0.142 & 17 \\
$1.0 \%$ & 1816 & 1550 & 203 & 0.836 & 0.661 & 0.154 & 18 \\
$1.5 \%$ & 1657 & 1380 & 241 & 0.737 & 0.531 & 0.181 & 25 \\
$2.0 \%$ & 1716 & 1377 & 299 & 0.896 & 0.561 & 0.300 & 33 \\
$2.5 \%$ & 1578 & 1206 & 322 & 0.929 & 0.474 & 0.415 & 45 \\
\hline
\end{tabular}

${ }^{1} S_{\mathrm{BET}}$, Brunauer-Emmett-Teller surface area; $S_{\text {micro, }}$ micropore surface area; $S_{\text {meso }}$, mesopore surface area; $V_{\text {tot }}$, total pore volume; $V_{\text {micro, }}$ micropore volume; $V_{\text {meso }}$, mesopore volume; and MP-ratio $=\left(V_{\text {meso }} / V_{\text {tot }}\right) \times 100 \%$.

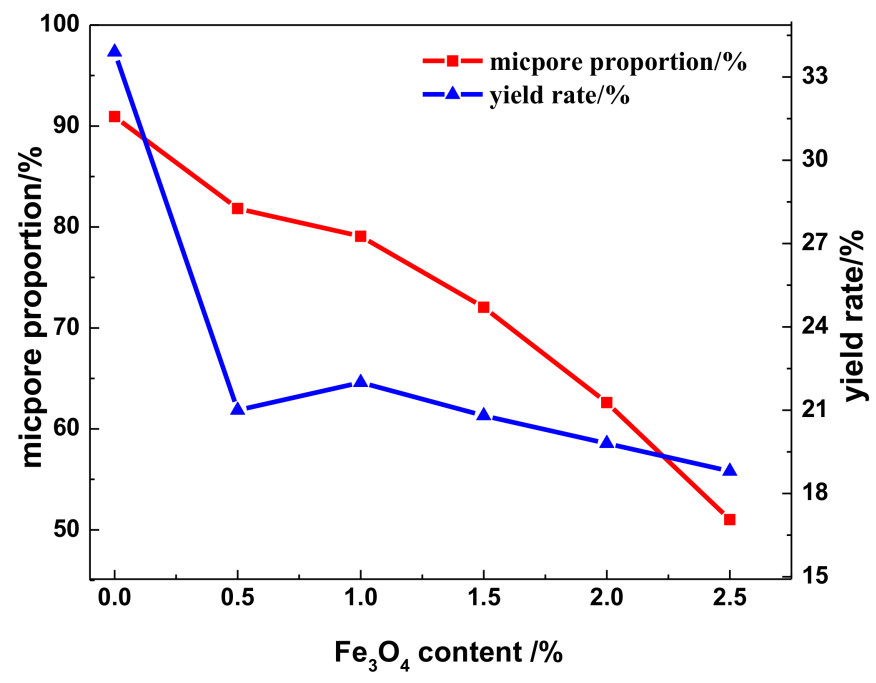

Figure 7. Micropore proportion and yield rate of the WMACFs.

\subsection{VSM Analysis of the WMACFs}

Figure 8 shows the magnetic hysteresis loop of the WMACFs. When the $\mathrm{Fe}_{3} \mathrm{O}_{4}$ content increased from $0.5 \%$ to $1.5 \%$, the WMACFs responded weakly to an external magnetic field. This is probably because the lower $\mathrm{Fe}_{3} \mathrm{O}_{4}$ content was not enough to make the WMACFs possess magnetic properties. Whereas when the $\mathrm{Fe}_{3} \mathrm{O}_{4}$ content was increased from $1.5 \%$ to $2.5 \%$, the very weak hysteresis revealed the resultant magnetic nanoparticles were nearly of magnetic properties with a saturation magnetization from 0.0129 to $0.0440 \mathrm{emu} / \mathrm{g}$. This meant that the $\mathrm{Fe}_{3} \mathrm{O}_{4}$ content was a key factor influencing the magnetic properties of the WMACFs. Because of the low nano- $\mathrm{Fe}_{3} \mathrm{O}_{4}$ content and small nanoparticle size, the saturation magnetization was relatively small. However, the samples still had adequate magnetization to be easily and quickly separated from the complex sample.

Table 4 shows the residual magnetization, saturation magnetization, and coercive force of the WMACFs. With increased $\mathrm{Fe}_{3} \mathrm{O}_{4}$ content, the saturation magnetization increased, which was probably due to the fact that the greater the $\mathrm{Fe}_{3} \mathrm{O}_{4}$ content, the more obvious the magnetism. The residual magnetization increased from 0.0037 to $0.0075 \mathrm{emu} / \mathrm{g}$. When the $\mathrm{Fe}_{3} \mathrm{O}_{4}$ content was $1.5 \%$, the coercive force reached its maximum, which was 270.4 Oe. The samples with $\mathrm{Fe}_{3} \mathrm{O}_{4}$ contents of $1.5 \%$ to $2.5 \%$ had certain residual magnetization and coercive force, which was due to the partial agglomeration of the $\mathrm{Fe}_{3} \mathrm{O}_{4}$ nanoparticles during the carbonization and activation process. 

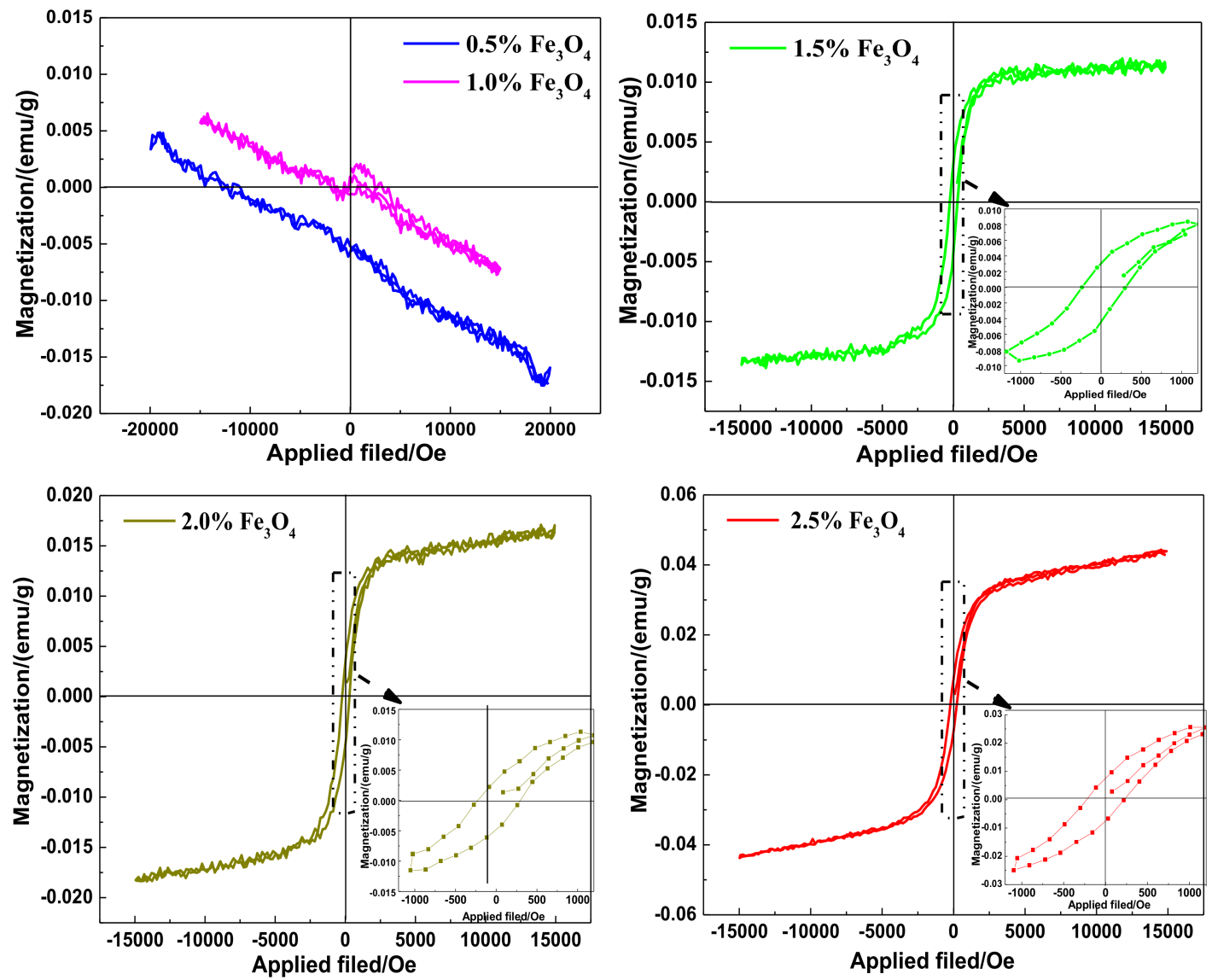

Figure 8. The magnetic hysteresis loop of the WMACFs.

Table 4. Residual magnetization, saturation magnetization, and coercive force of the WMACFs.

\begin{tabular}{lccccc}
\hline $\mathrm{Fe}_{3} \mathrm{O}_{4}$ Content & $\mathbf{0 . 5} \%$ & $\mathbf{1 . 0} \%$ & $\mathbf{1 . 5 \%}$ & $\mathbf{2 . 0} \%$ & $\mathbf{2 . 5 \%}$ \\
\hline Residual Magnetization $(\mathbf{e m u} / \mathbf{g})$ & - & - & 0.0037 & 0.0041 & 0.0075 \\
Saturation Magnetization $(\mathbf{e m u} / \mathrm{g})$ & - & - & 0.0129 & 0.0177 & 0.0440 \\
Coercive Force (Oe) & - & - & 270.4 & 261.3 & 224.1 \\
\hline
\end{tabular}

\section{Conclusions}

In this study, WMACFs were successfully synthesized by phenol liquefaction, adding nano- $\mathrm{Fe}_{3} \mathrm{O}_{4}$, and melt-spinning, as well as curing and activation. Nano- $\mathrm{Fe}_{3} \mathrm{O}_{4}$ existed on the surface and cross-sections of almost every WMACF. With increased $\mathrm{Fe}_{3} \mathrm{O}_{4}$ content, the yield rate of the WMACFs decreased, and the $\mathrm{Fe}_{3} \mathrm{O}_{4}$ crystal plane diffraction peaks were obviously heightened. The characteristic adsorption peaks of $\mathrm{Fe}-\mathrm{O}$ emerged at $594 \mathrm{~cm}^{-1}$ on the infrared spectrum. The WMACFs had a narrow distribution of micropore diameters $(0.5-1.2 \mathrm{~nm})$ and mesopore diameters $(2.0-3.0 \mathrm{~nm})$. Due to the pore-forming and pore-expanding function of $\mathrm{Fe}_{3} \mathrm{O}_{4}$, higher $S_{\mathrm{BET}}$ and more developed pore structures were achieved. When the $\mathrm{Fe}_{3} \mathrm{O}_{4}$ content was more than $1.5 \%$, it had favorable magnetic properties, which provided a reference value for the recovery of the WMACFs after adsorption saturation. The practical application of the WMACFs was limited because of the low $\mathrm{Fe}_{3} \mathrm{O}_{4}$ content, but this provides a new direction to explore wooden activated carbon fiber materials with highly developed multi-porous structures and magnetic properties for adsorption separation. It is expected to be used in supercapacitor electronic materials, wastewater treatment, and air purification, such as the adsorption of formaldehyde, as well as in carrier materials of photocatalyst due to its hierarchical pore structures, magnetic properties, and characteristics of doping metal oxide. 
Acknowledgments: This research has been financially supported by Opening Project Fund of Key Laboratory of Rubber Biology and Genetic Resource Utilization, Ministry of Agriculture/State Key Laboratory Breeding Base of Cultivation \& Physiology for Tropical Crops/Danzhou Investigation \& Experiment Station of Tropical Crops, Ministry of Agriculture (RRI-KLOF201801), and the National Natural Science Foundation of China (No. 31270607).

Author Contributions: Xiaojun Ma and Jianing Li conceived of and designed the experiments; Dongna Li, Biyun Ren, and Tongtong Li performed the experiments; all the authors analyzed the data; and Dongna Li, Biyun Ren, and Xiaojun Ma wrote the paper.

Conflicts of Interest: The authors declare no conflict of interest.

\section{References}

1. Li, D.N.; Ma, X.J. Preparation and characterization of activated carbon fibers from liquefied wood. Cellulose 2013, 20, 1649-1656. [CrossRef]

2. Huang, Y.X.; Zhao, G.J. A novel method for the production of mesoporous activated carbon fibers from liquefied wood. Mater. Lett. 2016, 178, 190-192. [CrossRef]

3. Kwiatkowski, M. Analysis of the microporous structure of the low-cost activated carbon fibres obtained from flax and jute cloth. J. Math. Chem. 2017, 55, 1893-1902. [CrossRef]

4. Yue, Z.R.; Vakili, A. Activated carbon-carbon composites made of pitch-based carbon fibers and phenolic resin for use of adsorbents. J. Mater. Sci. 2017, 52, 12913-12921. [CrossRef]

5. Huang, Y.; Ma, E.; Zhao, G. Thermal and structure analysis on reaction mechanisms during the preparation of activated carbon fibers by $\mathrm{KOH}$ activation from liquefied wood-based fibers. Ind. Crop. Prod. 2015, 69, 447-455. [CrossRef]

6. Ma, X.J.; Zhang, F.; Wei, L.Q. Effect of wood charcoal contents on the adsorption property, structure, and morphology of mesoporous activated carbon fibers derived from wood liquefaction process. J. Mater. Sci. 2015, 50, 1908-1914. [CrossRef]

7. Ma, X.J.; Yang, H.; Yu, L.; Chen, Y.; Li, Y. Preparation, surface and pore structure of high surface area activated carbon fibers from bamboo by steam activation. Materials 2014, 7, 4431-4441. [CrossRef] [PubMed]

8. McEvoy, J.G.; Zhang, Z.S. Synthesis and characterization of magnetically separable Ag/AgCl-magnetic activated carbon composites for visible light induced photocatalytic detoxification and disinfection. Appl. Catal. B Environ. 2014, 267-278. [CrossRef]

9. Zhang, S.L.; Tao, L.C.; Jiang, M.; Gou, G.J.; Zhou, Z.W. Single-step synthesis of magnetic activated carbon from peanut shell. Mater. Lett. 2015, 157, 281-284. [CrossRef]

10. Bai, X.; Qin, C.D.; Huang, X. Voltammetric determination of chloramphenicol using a carbon fiber microelectrode modified with $\mathrm{Fe}_{3} \mathrm{O}_{4}$ nanoparticles. Microchim. Acta 2016, 183, 2973-2981. [CrossRef]

11. Li, C.D.; Lu, J.J.; Li, S.M.; Tong, Y.B.; Ye, B.C. Synthesis of Magnetic Microspheres with Sodium Alginate and Activated Carbon for Removal of Methylene Blue. Materials 2017, 10, 84. [CrossRef] [PubMed]

12. Shi, Q.Q.; Li, A.M.; Zhou, Q.; Shuang, C.D.; Li, Y.; Ma, Y. Utilization of waste cation exchange resin to prepare carbon/iron composites for the adsorption of contaminants in water. J. Ind. Eng. Chem. 2014, 20, 4256-4260. [CrossRef]

13. Yang, N.; Zhu, S.M.; Zhang, D.; Xu, S. Synthesis and properties of magnetic $\mathrm{Fe}_{3} \mathrm{O}_{4}$-activated carbon nanocomposite particles for dye removal. Mater. Lett. 2008, 62, 645-647. [CrossRef]

14. Majeed, M.I.; Guo, J.; Yan, W.; Tan, B. Preparation of magnetic iron oxide nanoparticles (MIONs) with improved saturation magnetization using multifunctional polymer ligand. Polymers 2016, 8, 392. [CrossRef]

15. Hai, H.; Grinblat, J.; Sougrati, M.T.; Stievano, L.; Margel, S. Engineering of Iron-Based Magnetic Activated Carbon Fabrics for Environmental Remediation. Materials 2015, 8, 4593.

16. Chen, H.Y.; Du, Y.; Lu, Q. Microwave-assisted rapid synthesis of $\mathrm{Fe}_{2} \mathrm{O}_{3} / \mathrm{ACF}$ hybrid for high efficient $\mathrm{As}(\mathrm{V})$ removal. J. Alloy. Compd. 2016, 674, 399-405. [CrossRef]

17. Ma, X.J.; Zhao, G.J. Preparation of carbon fibers from liquefied wood. Wood Sci. Technol. 2010, 44, 3-11.

18. Ma, X.J.; Zhao, G.J. Variations in the microstructure of carbon fibers prepared from liquefied wood during carbonization. J. Appl. Polym. Sci. 2011, 121, 3525-3530. [CrossRef]

19. Ma, X.J.; Zhang, F.; Zhu, J.Y.; Yu, L.L.; Liu, X.Y. Preparation of highly developed mesoporous activated carbon fiber from liquefied wood using wood charcoal as additive and its adsorption of methylene blue from solution. Bioresour. Technol. 2014, 164, 1-6. [CrossRef] [PubMed] 
20. Ma, X.J.; Chen, Y. Preparation and characterization of $\mathrm{Mn} / \mathrm{N}$ co-doped $\mathrm{TiO}_{2}$ loaded on wood-based activated carbon fiber and its visible light photodegradation. Polymers 2015, 7, 1660-1673. [CrossRef]

21. Foo, K.Y; Hameed, B.H. Mesoporous activated carbon from wood sawdust by $\mathrm{K}_{2} \mathrm{CO}_{3}$ activation using microwave heating. Bioresour. Technol. 2012, 111, 425-432. [CrossRef] [PubMed]

22. Johnson, D.J.; Frank, C. Recent Advances in Studies of Carbon Fiber Structure. Philos. Trans. 1980, 294, 443-449. [CrossRef]

23. Cuesta, A.; Dhamelincout, P.; Laureyns, J.; Martinezalonso, A.; Tascon, J.M.D. Comparative performance of X-ray diffraction and Raman microprobe techniques for the study of carbon materials. J. Mater. Chem. 1998, 8, 2875-2879. [CrossRef]

24. Zou, D.Y.; Zhang, B.H.; Liao, B.G.; Chen, C.G.; Zhang, Q. Study of determining the degree of graphitizing of coke with X-ray diffraction method. J. Chongqing Univ. 1988, 6, 83-93.

25. Anirudhan, T.S.; Sreekumari, S.S. Adsorptive removal of heavy metal ions from industrial effluents using activated carbon derived from waste coconut buttons. J. Environ. Sci. 2011, 23, 1989-1998. [CrossRef]

26. Groen, J.C.; Peffer, L.A.; Javier, P.R. Pore size determination in modified micro-and mesoporous materials. Pitfalls and limitations in gas adsorption data analysis. Microporous Mesoporous Mater. 2003, 60, 1-17. [CrossRef]

27. Elmerraoui, M.; Aoshima, A.M.; Kaneko, K. Micropore Size Distribution of Activated Carbon Fiber Using the Density Functional Theory and Other Methods. Langmuir 2000, 16, 4300-4304. [CrossRef]

28. Kubo, S.; Yoshida, T.; Kadia, J.F. Surface porosity of lignin/PP blend carbon fibers. J. Wood Chem. Technol. 2007, 27, 257-271. [CrossRef]

29. Li, G.L.; Jiang, Y.R.; Huang, K.L.; Ding, P.; Yao, L.L. Kinetics of adsorption of Saccharomycescerevisiae mandelated dehydrogenase on magnetic $\mathrm{Fe}_{3} \mathrm{O}_{4}$-chitosannanoparticles. Colloids Surf. A 2008, 320, 11-18. [CrossRef]

30. Dai, C.C.; Wan, J.F.; Shao, J.Q.; Ma, F.W. Hollow activated carbon with unique through-pore structure derived from reed straw for high-performance supercapacitors. Mater. Lett. 2017, 193, 279-282. [CrossRef]

31. Qiang, C.W.; Xu, J.C.; Zhang, Z.Q.; Tian, L.L.; Xiao, S.T.; Liu, Y.; Xu, P. Magnetic properties and microwave absorption properties of carbon fibers coated by $\mathrm{Fe}_{3} \mathrm{O}_{4}$ nanoparticles. J. Alloys Compd. 2010, 506, $93-97$. [CrossRef]

32. Ramesh, T.; Rajalakshmi, N.; Dhathathreyan, K.S. Synthesis and characterization of activated carbon from jutefibers for hydrogen storage. Renew. Energy Environ. Sustain. 2017, 2, 27-36. [CrossRef]

33. Ge, X.Y.; Wu, Z.S.; Wu, Z.L.; Yan, Y.J.; Cravotto, G.C.; Ye, B.C. Microwave-assisted modification of activated carbon with ammonia for efficient pyrene adsorption. J. Ind. Eng. Chem. 2016, 39, 27-36. [CrossRef]

34. Jin, G.; Eom, Y.J.; Lee, T.G. Removal of $\mathrm{Hg}$ (II) from aquatic invironments using activated carbon impregnated with humic acid. J. Ind. Eng. Chem. 2016, 42, 46-52. [CrossRef]

35. Lee, Y.S.; Basova, Y.V.; Edie, D.D.; Reid, L.K.; Newcombe, S.R.; Ryu, S.K. Preparation and characterization of trilobal activated carbon fibers. Carbon 2003, 41, 2573-2584. [CrossRef]

36. Zhang, S.J.; Feng, H.M.; Wang, J.P.; Yu, H.Q. Structure evolution and optimization in the fabrication of PVA-based activated carbon fibers. J. Colloid Interface Sci. 2008, 321, 96-102. [CrossRef] [PubMed]

(C) 2018 by the authors. Licensee MDPI, Basel, Switzerland. This article is an open access article distributed under the terms and conditions of the Creative Commons Attribution (CC BY) license (http:/ / creativecommons.org/licenses/by/4.0/). 